OSOBA I SAMOTNOŚĆ. MIĘDZY CODZIENNOŚCIĄ A MISTYKĄ

Filozofia Chrześcijańska • Tom 12, Poznań 2015

Uniwersytet im. Adama Mickiewicza w Poznaniu - Wydziat Teologiczny doi: 10.14746/fc.2015.12.05

\title{
Samotność pacjenta i lekarza wobec decyzji o leczeniu inwazyjnym w chirurgii
}

Loneliness of the Patient and Doctor in the Face of the Decision about Undertaking a Surgery

\author{
Pamięci moich Rodziców, \\ Dtadystawa i Olgi z Bogdanowiczów, \\ pracę tę poświęcam - \\ autor.
}

Samotność, jeżeli istnieje, jest zjawiskiem sprzężonym z tożsamością z poczuciem odrębności, dochodzącym do świadomości podmiotu zwykle w relacji ,ja”„inne ja”, po doświadczeniu obojętności bliskiego lub obcego człowieka, względnie innych ludzi. Podmiot oczekuje wówczas: współodczuwania, współrozumienia, pomocy lub tylko obecności. W sferze emocji często możemy obserwować obniżenie nastroju, ale nie jest ono koniecznym warunkiem samotności.

Symptomatologią i diagnozowaniem musieli zajać się dramatopisarze i poeci, ponieważ my, dbając o dobre obyczaje i zachowanie więzi ze wspólnotami, milczymy. Samotność Homera poznaliśmy, w różnych jej odmianach, dzięki postaciom Palamedesa, Achillesa, Ajaksa; samotność Juliusza Słowackiego w Horsztyńskim, Mazepie, Beniowskim, Williama Szekspira m.in. w Sonecie 66. Mając w pamięci słowa z I aktu III części Dziadów Adama Mickiewicza, nie możemy pominąć kilku pytań:

1. Czy s a motn ość występuje jedynie jako poetycka fraza, konwencja językowa?

2. Jeżeli jest tylko w obszarze konwencji, to czy odrzucamy wówczas pojęcie sensu?

3. Jeśli istnieje również - lub przede wszystkim - poza obszarem gier językowych, to jak możemy ją zbadać, szczególnie u „Innego”, skoro on milczy lub - być może - nie zechce być szczery? 
Wśród konsekwencji twierdzącej odpowiedzi na pierwsze i drugie pytanie trudno zlekceważyć odejście od konieczności sensu. Przywołajmy przykład zgody pacjenta na zabieg operacyjny. Zgoda taka ma sens tylko wówczas, gdy jest odpowiedzią udzieloną przez tego właśnie pacjenta na propozycję chirurga dotyczącą wyraźnie określonego zabiegu operacyjnego, w tych - a nie innych - okolicznościach i tylko w tym czasie. Zgoda pacjenta, bez jasno określonej decyzji chirurga, w nieokreślonym czasie i warunkach - nie ma sensu. W chirurgii naczyniowej bywa tak, że dana operacja, która ratuje teraz, przeprowadzona w kilka godzin później sprowadza na pacjenta ogromne ryzyko, wykonana następnego dnia może zabić. Wytłumaczenie cierpiącemu i zestresowanemu choremu zawiłości patofizjologii nie jest zwykle możliwe, a może powiększyć stres. Co więcej, nie jest tym samym propozycja wykonania „tej samej”, trudnej operacji, złożona temu samemu pacjentowi kolejno przez dwóch chirurgów różniących się doświadczeniem w tym typie operacji. Nierzadko zdrowie i życie pacjenta zależy od umiejętności rozpoznania przez chirurga nietypowego wariantu przebiegu naczyń i konieczności wymyślenia ad hoc modyfikacji planu lub unikatowej operacji. Pacjent wówczas śpi i choć może ma nawet coś $\mathrm{z}$,wzorca zobiektywizowanego pacjenta rozsądnego", to znaczenie mają jedynie: życzliwość, wiedza, talent operatora i jego zespołu oraz zaufanie pacjenta, które ma moc zobowiązywania.

Gdyby samotność miała należeć jedynie do gier językowych, byłaby najczęściej rozpoznawana u osób zadowalających się namiastkami i wirtualnymi formami uczestnictwa. Tymczasem postrzegamy coś przeciwnego. Im silniejsza osobowość, większy zakres indywidualnej odpowiedzialności i bardziej autentyczne życie, tym wyraźniej rysuje się możliwość samotności. Osoby takie musza, z konieczności, uczyć się pogodnego jej dźwigania, aby zachować szczególną pozycję w społeczeństwie wraz z radością istnienia.

Wypada zatem zgodzić się na istnienie samotności przede wszystkim poza obszarem gier językowych, tam gdzie emocje łączą się z poczuciem odrębności istnienia.

Zbadanie samotności u „Innego" natrafia na wspomniane wyżej trudności, a ponadto do milczącej powściągliwości badanego należałoby dołączyć podobną u badającego. Lepiej będzie wybrać taki model badawczy, w którym przemówią raczej czyny, decyzje, niż tylko słowa. Dlatego wybrałem sytuację graniczną, o której milczał Karl Jaspers: decyzję o zabiegu inwazyjnym w chirurgii.

W rozważaniach na temat samotności pacjenta i chirurga poszukuję odpowiedzi na kilka pytań:

1. Czy mówienie o samotności jest zawsze krytyką wspólnoty; czy źródła samotności tkwią raczej w samej istocie bytu indywidualnego człowieka?

2. Związanie samotności z tożsamością nie budzi wątpliwości; jak wobec tego można samotności uniknąć lub ją złagodzić w sytuacji granicznej, w przypadku decyzji o zabiegu inwazyjnym? 
3. Jaki wpływ wywiera c za s na doświadczanie samotności w obliczu decyzji operacyjnej?

Trudno byłoby zbliżyć się do odpowiedzi na te pytania bez omówienia: antynomii samotności i wspólnoty, decyzji jako jednego z czynników konstytuujących tożsamość i bez podzielenia się niektórymi spostrzeżeniami z wieloletniej własnej praktyki chirurgicznej.

\section{ANTYNOMIE SAMOTNOŚCI I WSPÓLNOTY}

Wspólnota rodziny lub religijna jest naturalnym środowiskiem rozwoju i ograniczania wolności człowieka. Wspólnoty te zostają nam narzucone, podobnie jak geny i moment poczęcia życia, a także prawa i obowiązki uchwalone przez parlamenty przed naszym urodzeniem. To, że płyniemy w nurcie historii rodziny, narodu i innych wspólnot, antycypuje naszą wolę mocy, a może być powodem do dumy i spajać te wspólnoty. Również niewielkie ograniczenie wolności nie musi być rozumiane jako wezwanie do sprzeciwu, szczególnie gdy jest koniecznym warunkiem uratowania wolności, zwłaszcza zagrożonej z zewnątrz.

Rodzina stanowi wzorzec dla związków między ludźmi, dlatego zmiany w niej zachodzace są ważne i dla innych wspólnot. Czy samotność ma do rodziny prawo wstępu? Wiemy, że tak, ale wolimy to przeżywać w teatrze: wraz z Hamletem podczas jego spotkania z matką lub z Antygoną po jej rozmowie z siostrą Ismena. Do własnej rodziny chcielibyśmy dopuścić samotność jedynie w przypadku demonstrowania przez dziecko: poczucia bezpieczeństwa, rozwinięcia samodzielnego myślenia i wyobraźni ${ }^{1}$. Słuszne wydają się niektóre spostrzeżenia Anthony'ego Storra „[...] zdolność do przebywania w samotności również stanowi jeden z aspektów dojrzałości emocjonalnej”, „Samotność stwarzająca podstawy dla rozwoju wyobraźni może obudzić w dziecku potencjał twórczy", „[...] pewien rozwój zdolności do przebywania w samotności jest niezbędny, by mózg mógł pracować osiagając maksymalny poziom swoich możliwości [...]".

Tworzenie innych związków, na przykład wspólnoty narodów jednego języka, wymaga już silnego wsparcia ideowego, określenia celów, wskazania wspólnego wroga oraz innych warunków, które w 1924 roku podał Helmuth Plessner w rozdziale „Krew i sprawa”. „1. więź krwi jej członków, 2. miłość, która jednoczy i której promienie skupiają się na powszechnie czczonym wodzu, 3. wódz, «pan i mistrz», bez tej postaci, która stanowi centrum, nie może istnieć żadna wspólnota". Co się dzieje z tożsamością pojedynczego człowieka w takiej wspól-

${ }^{1}$ A. Storr, Samotność - powrót do jaźni, tłum. J. Prokopiuk, P.J. Sieradzan, Warszawa 2010, s. $42,43,55$.

${ }^{2}$ H. Plessner, Granice wspólnoty, tłum. J. Merecki, Warszawa 2008, s. 55. 
nocie, powiedział Plessner w innym miejscu ${ }^{3}$.,Pojedyncza, zamknięta w sobie osoba rezygnuje z siebie, aby na nowo otrzymać swoją niezależność z wyższego źródła bytu, z więzi wszystkich członków". Wielu jednak filozofów miało zupełnie inny ogląd tej sprawy. Max Scheler, który dużo uczynił dla poszerzenia wiedzy o wartościach, wątpił w ich oddziaływanie na szersze kręgi społeczeństwa. Zauważył, że odosobnienie jest przez ludzi „dobrych” znoszone znacznie łatwiej niż przez bardziej grzesznych, ale ,[...] to wyzwala coś w rodzaju wstrętu do tych dobrych ludzi, którzy mogą znieść tę samotność [...]"4. Nieco dalej dostrzega słabość w tendencji do chowania się we wspólnocie: „Człowiek powodowany resentymentem jest słabeuszem; w swym sądzie nie może być odosobniony”. Cyrenajczycy Arystyp i Teodor, a później T. Hobbes i José Ortega y Gasset nie pozostawiają cienia wątpliwości co do nieuleczalnej samotności człowieka. Hobbes wskazuje na fałszywość sądu ,[...] że człowiek jest zwierzęciem z urodzenia sposobnym do życia społecznego, czyli jak mówią Grecy: zoon politikon [...]", Ortega y Gasset podkreśla, że człowiek pozostaje absolutną, czystą samotnością. Drugi człowiek to druga samotność, tylko człowiek może być samotny, właśnie dlatego że nie jest jedyny, ale że istnieją inni. Samotnym jest się więc pośród innych albo - lepiej - z innymi ${ }^{6}$.

Hobbes miał własną praktykę w dziedzinie polityki; skoro zatem usuną człowieka z arystotelesowskiej wspólnoty istot społecznych, jak pisze Ryszard Wiśniewski: ,[...] podejmuje się nałożenia na empiryczną mapę ludzkich dążeń racjonalnej, apriorycznej siatki zasad. Podstawowa zasada systemu, jaki rozum ma wprowadzić, polega jednak na podniesieniu do rangi aksjomatu motywu maksymalnej realizacji interesu jednostkowego" ". Autor Lewiatana tak broni tożsamości indywidualnego człowieka przed ewentualnymi roszczeniami wspólnot: „Pierwszym spośród dóbr jest zachowanie własnej osoby. Tak bowiem uczyniła natura, iż każdy chce swego dobra. Ażeby każdy mógł je osiagnąć, trzeba koniecznie, iżby pragnął życia, zdrowia oraz bezpieczeństwa [...]"8.

Nie ma tu krytyki wspólnoty; zanim społeczności rozwinęły się w narody i państwa, istniał priorytetowy cel każdej osoby: obrona życia w jego jednostkowej odrębności.

\footnotetext{
${ }^{3}$ Tamże, s. 51.

${ }^{4}$ M. Scheler, Resentyment a moralność, tłum. Jan Garewicz, Warszawa 1997, s. 113.

${ }^{5}$ Tamże, s. 176.

${ }^{6}$ M. Chlewicki, Fenomen społeczny w filozoficznym ujęciu Jose Ortegi y Gasseta, w: S. Sarnowski, M. Korzeniowska, M. Chlewicki, O metafilozofii jako filozofii filozofii, Warszawa 2007, s. 162. M. Chlewicki zwrócił uwagę na propozycję Gasseta, nawiązującą do Leibniza, „[...] by monadę rozumieć nie metafizycznie, nie jako byt, substancję duchową, ale jako ludzką samotność" -

${ }^{7}$ W. Tyburski, A. Wachowiak, R. Wiśniewski, Historia filozofii i etyki. Źródła i komentarze, Toruń 1997, s. 321.

${ }^{8}$ Tamże, s. 321. T. Hobbes: Elementy filozofii, thum. C. Znamierowski, Warszawa, 1956, s. 128.
} s. $163,164$. 
Czy w samej konstrukcji wspólnoty zawarty jest mechanizm ochronny przed zlepieniem odrębnych istnień ludzkich w formę wyłączającą możliwość zachowania jednostkowej tożsamości, czy raczej problem ten rozstrzyga się w walce? Za którym rozwiązaniem opowiedziałby się Immanuel Kant? ,[...] co do jednej kategorii, mianowicie co do kategorii wspólnoty [...] jest ona zgodna z odpowiadająca jej w zestawieniu funkcji logicznych formą sądu rozłącznego" ". I wyjaśnia

Żeby się upewnić co do tej zgodności, trzeba zauważyć, że we wszystkich sądach rozłącznych dziedzina (mnogość tego wszystkiego, co pod ten sąd podpada) jest przedstawiona jako całość podzielona na części [...], a ponieważ jedna z nich nie może być zawarta w drugiej, więc są one pomyślane jako sobie przyporządkowane, a nie podporządkowane. Przeto określają się one nie jednostronnie jak w szeregu, lecz wzajemnie jak w agregacie (jeżeli przyjmujemy jeden człon podziału, to wykluczamy wszystkie pozostałe i odwrotnie) ${ }^{10}$.

Autor tego szkicu ma świadomość, że szczególnie to ostatnie zdanie Kanta musi być ostrożnie odczytywane w odniesieniu do rodziny lub wspólnoty religijnej.

Poznawanie „Innego” i postawa życzliwości zaliczane są do spoiw wspólnoty, skutecznych w rozpraszaniu samotności. Napotykamy tu jednak na trudności.

Stanisław Judycki, rozważając konsekwencje redukcji transcendentalnej Edmunda Husserla, zauważa, że po dokonaniu redukcji „Inni”, a także świat, są przyjmowani jako korelat świadomości, a to już prowadzi do solipsyzmu, który mogłoby jedynie uchylić wykazanie udziału w konstytuowaniu świata przez „Innych”. W Medytacjach Kartezjańskich Husserl mówi: „To, co da się zawsze źródłowo uobecnić i wykazać, jest mną samym [...]"11. Trudno uzyskać pewną wiedzę o Drugich, ponieważ Drugi nigdy nie może być dany jako Drugi, źródłowo, lecz zawsze tylko pośrednio. Podobnie i cudzy czas nigdy nie jest nam dany źródłowo, lecz zawsze tylko jako uobecniony, a wspólnota może być jedynie modelowana na wzór samego siebie ${ }^{12}$.

Życzliwość budzi mniej zastrzeżeń. Omawiając naukę Annikerisa, Adam Krokiewicz pisze: ,[...] nikt nie przeżywa cudzego szczęścia bezpośrednio (eudaimonian... me aisteten to pelas hyparchein), niemniej jednak godzi się dbać o przyjaciela po części «z potrzeby», po części zaś z - serdecznej życzliwości"13. Powinna się ona objawiać bardziej w czynach niż w słowach, już choćby $z$ tego

\footnotetext{
${ }^{9}$ I. Kant, Krytyka czystego rozumu, thum. R. Ingarden, Kraków 1957, t. 1, s. 178.

${ }^{10}$ Tamże, s. 179.

${ }^{11}$ S. Judycki, Intersubiektywność i czas. Przyczynek do dyskusji nad późnq faza pogladów Edmunda Husserla, Lublin 1990, s. 104, 112, 113.

12 Tamże, s. 104, 79, 270-271.

${ }^{13}$ A. Krokiewicz, Etyka Demokryta i hedonizm Arystypa, Warszawa 1961, s. 190.
} 
powodu, że język codziennej komunikacji, zwany przez Ferdynanda de Saussure'a - parole, w małym stopniu nadaje się do budowania prawdziwego porozumienia i przekazywania głębszych treści. W dobrą wolę porozumienia wątpił nie tylko Hegezjasz, ale i Henryk Elzenberg ${ }^{14}$. Tu również nie ma pewności z powodów epistemicznych, o których pisał S. Judycki. Trudno przekazać Drugiemu swe dobre intencje. Zaufanie, zranione przez innych, regeneruje się znacznie wolniej niż uszkodzony nerw obwodowy. Posługując się uproszczonymi środkami komunikowania, doszliśmy do stanu, w którym, jak to cierpko stwierdza E. Cassirer, „Zamiast zajmować się rzeczami samymi w sobie, człowiek w pewnym sensie ustawicznie rozmawia sam z sobą" 15 .

Wychodząc z tych rozważań w stronę praxis, wracam do problemu pacjenta, któremu chirurg zaproponował poważny zabieg operacyjny dla ratowania zdrowia lub życia. Czy może zaufać „Innemu”, wspólnocie, w ramach której będzie działał zespół kierowany przez chirurga? Pacjent, który do opinii Elzenberga łatwo dorzuciłby własne podobne spostrzeżenia, nie pożąda sprawiedliwości, raczej będzie szukał ratunku w wielkodusznej łaskawości Boga (hanan) ${ }^{16}$.

\section{DECYZJA}

Podejmowanie decyzji jest jednym ze źródeł tożsamości człowieka, dowodem posiadanej wolności i ujawnieniem prawdziwego stosunku do dóbr, zwanych także wartościami. Zbigniew Zwoliński wśród warunków formalnych odpowiedzialności zwrócił uwagę na ,[...] istnienie ontycznej struktury świata, w której możliwe jest kontrolowane przez podmiot realizowanie wybranych przezeń możliwości" ${ }^{17}$. Mówimy tu nie tylko o właściwej selekcji osób, które maja zostać lekarzami i pielęgniarkami, nie tylko o poziomie studiów, specjalizacji, organizacji pracy i wyposażenia w odpowiednią aparaturę, lecz przede wszystkim myślimy o wspólnej podstawie wzajemnego zaufania, która - zdaniem Seweryna Szatkowskiego - byłaby zawarta ,[...] w istnieniu jednej, ogólnie akceptowanej moralności”. Dzisiaj „Pacjent po prostu nie wie, jaka jest postawa lekarza wobec życia i śmierci, jakie jest jego wyobrażenie dobra i zła. Bez zaufania pacjenta praca lekarza staje się jednak zupełnie nie do pomyślenia" ${ }^{18}$. Postawa życz-

${ }^{14}$ M. Tyl, W stronę Eleusis, „Znak” 2001, nr 553, s. 95-106. M. Tyl cytuje słowa H. Elzenberga: „Z mojego punktu widzenia człowiek jest zasadniczo i esencjonalnie istotą złej woli” - s. 98.

${ }^{15}$ E. Cassirer, Człowiek i kultura, s. 12-29, są to fragmenty książki E. Cassirera, Esej o człowieku. Wstęp do filozofii kultury, tłum. A. Staniewska, Warszawa 1977, s. 79-84, 90-100, w: Kierunki filozofii współczesnej, red. J. Pawlak, Toruń, 1995, cz. II, s. 98.

${ }_{16}$ Jan Paweł II, Encyklika Dives in misericordia, Warszawa 2007, s. 29, 30.

${ }^{17}$ Z. Zwoliński, Istota odpowiedzialności. Warunki formalne i granice, ,Etyka” 23(1993), s. 13.

${ }^{18}$ S. Szatkowski, Zasada nieuszkodzenia w etyce medycyny, „Etyka” 29(1996), s. 155-169, s. 168. Istnieje uzasadniona obawa, że część lekarzy już teraz jest gotowa uznać, że lekarz to taki 
liwości i szacunku dla pacjenta, połączone z dużą wiedzą, silną osobowością i odwagą lekarza dobrze chronią pacjenta, znacznie mniej lekarza. Wielu lekarzy ulega naciskom i modom.

Stojąc na gruncie „orientacji prakseologicznej”, lekarz nie bierze pod uwage - przy ustalaniu priorytetów - stopnia schorzenia pacjentów, lecz kieruje się wyłącznie „wymiarem" społecznym ich osobowości oraz przewidywaną skutecznością [...]. W przypadku zaś odwołania się do „orientacji utylitarystycznej” jedynym kryterium selekcji chorych i rozdziału środków diagnostyczno-terapeutycznych jest ich aktualny i przewidywany w przyszłości status społeczny ${ }^{19}$.

Wybory dokonane przez lekarza mają swe źródło nie tylko w genach. Działania lub zaniechania, które wynikają z decyzji, rzeźbią w czasie i świadomości, z pomocą pamięci, odrębność historii każdego człowieka. „Tylko przyszłość nie jest jeszcze gotowa, czyli stoi otworem przed czynną wolą"20 pisze Nicolai Hartmann, dodając $\mathrm{w}$ innym miejscu „Indywidualny byt duchowy istnieje tylko w swych dokonaniach" ${ }^{21}$. Karol Jaspers badał ten problem w sytuacjach gra n i z z y ch, do których zaliczył: śmierć, cierpienie, walkę i winę. Pisze on „Właśnie wtedy stajemy się sami sobą, gdy z otwartymi oczami wkraczamy w sytuacje graniczne. [...] Przeżywać sytuacje graniczne i egzystować to jedno i to samo. Wobec bezradności istnienia empirycznego jest to wzlot bytu [Seins] we mnie. [...] Tak więc zdobywam mój własny byt w absolutnej samotności [...]”22.

Nie wydaje się, aby była to ta samotność, która jest zajęta analizą „,[...] zasady maksymalizowania przeciętnej wartości"23. Klemens Szaniawski opisuje dwie drogi dla racjonalnie wybierającego decydenta: (1) Jeżeli potrafi ocenić ,względne szanse realizacji następstw poszczególnych działań, powinien wybrać to działanie, które przynosi skutki o najwyższej wartości przeciętnej”, (2) „Jeżeli natomiast decydent nie dysponuje wiedza, która pozwoliłaby mu przypisać prawdopodobieństwa konsekwencjom poszczególnych działań, to nie istnieje kryterium, o którym dałoby się bezspornie dowieść, że jest najlepsze". Pacjent

sam zawód jak inne, i nie zechce ryzykować swoją karierą i zdrowiem dla ratowania życia pacjenta. S. Szatkowski, Zasada życzliwości w medycynie, „Etyka” 1994, nr 27, s. 103-117, omawiając zagrożenie życia chirurga, który ma operować pacjenta z HIV, pisze „,[..] jedyna możliwość uznania, że na lekarzu spoczywa w tej sytuacji obowiązek życzliwego działania, wynikałaby z potraktowania relacji lekarz-pacjent jako szczególnej relacji moralnej. Byłoby to możliwe przy założeniu, że lekarz to coś więcej, niż zawód [...]" - s. 115.

${ }^{19}$ T. Gonet, Problem wyboru moralnego w medycynie wspótczesnej, „Archiwum Historii i Filozofii Medycyny” 1988, 51, z. 1, s. 11. Podobne stanowisko zają T. Gonet w pracy Etyczny aspekt pobierania ludzkich narzqdów do przeszczepiania, „Archiwum Historii i Filozofii Medycyny”1990, 53, z. 4, s. 179-185.

\footnotetext{
${ }^{20}$ N. Hartmann, Systematyczna autoprezentacja, tłum. J. Garewicz, Toruń, 1994, s. 119.

${ }^{21}$ Tamże, s. 110.

${ }^{22}$ R. Rudziński, Jaspers, Warszawa, 1978 s. 190. Oryg.: K. Jaspers, Philosophie, Bd 1-3, 1932.

${ }^{23}$ K. Szaniawski, Teoria decyzji a etyka, ,Etyka” 2 (1967), s. 7, 8.
} 
niemal zawsze jest w tej drugiej sytuacji, ponieważ nie dysponuje wiedzą i doświadczeniem, które stanowią warunek wstępny takiej decyzji.

Wyobraźmy sobie studenta V roku medycyny, który swą supererogacyjna aktywnością na ostrym dyżurze zasłużył na uczestnictwo w konsultacjach poprzedzających decyzję operacyjną. Wyczerpująco „poinformowany” i „objaśniony" przez doświadczonego chirurga, zapytany, co należy zrobić w danej sytuacji, może odpowiedzieć: Nie wiem, nie mam w ogóle doświadczenia, a za mało mam wiedzy, aby wziąć odpowiedzialność za moje przypuszczenia. To jest za poważna sprawa; tu chodzi o życie pacjenta.

Natomiast od pacjenta niektórzy oczekują, że będzie „kompetentny” w dziedzinie chirurgii jelit, chirurgii endokrynologicznej, naczyniowej etc., i to właśnie wówczas, gdy bardzo źle się czuje. Decyzja pacjenta nie jest wyborem między możliwymi rozpoznaniami choroby i między metodami leczenia, co wydaje się łatwe jedynie osobom zupełnie pozbawionym wiedzy. Bardziej przypomina podpis króla lub prezydenta, który może dekret ministra lub ustawę parlamentu zatwierdzić względnie odrzucić, ale nie może stworzyć treści tych dokumentów. W tym podpisie pacjenta wyraża się godność człowieka, jego suwerenność w dysponowaniu swym zdrowiem i życiem. Może odmówić zgody i wybrać innego lekarza, któremu bardziej ufa.

Pacjent zatwierdza lub odrzuca decyzję chirurga; ma do tego prawo, ponieważ decyzja ta dotyczy jego własnego zdrowia i życia. O decyzjach dotyczących innych pacjentów nie ma prawa się wypowiadać i nie powinien - ze względu na dobre obyczaje.

Czy chory może zmodyfikować przedstawiony właśnie projekt terapii? Trzeba założyć, że chirurg proponuje najkorzystniejszą dla pacjenta metodę leczenia. Jeśli pacjent nie może lub nie chce jej zaakceptować, to wspólnie z chorym lekarz szuka rozwiązania najmniej szkodliwego dla pacjenta. Należy jednak pamiętać, że na przykład w przypadku perforacji wrzodowej dwunastnicy jest zagrożone życie chorego. Można wykonać najmniejszą możliwą operację, która ratuje życie, można wykonać nieco poważniejszą, która pozwoli zapobiegać nawrotowi choroby etc., lecz odstapić od operacji zwykle nie wolno. Lekarze nie chcą i nie powinni uczestniczyć w wyrafinowanych samobójstwach pacjentów.

Decyzja chirurga dotycząca zabiegu inwazyjnego nie jest informacja, „poinformowaniem", radą zaleceniem ani luźną propozycją którą będzie można pominać milczeniem. Chirurg, zwłaszcza chirurg specjalista, odpowiedzialności nie może uniknać ani przerzucić na innych, przeciwnie: bierze również odpowiedzialność za błędy popełnione przez członków swojego zespołu. Jeżeli poprosi o konsultację bardziej doświadczonego kolegę, to nic się tu nie zmienia poza ewentualnie jakąś podpowiedzią lub sugestią innego lekarza, który pozostaje tylko konsultantem.

Po zebraniu wszystkich danych $\mathrm{z}$ badań i konsultacji chirurg musi w $\mathrm{s}$ a motnośc i podjąć decyzję i przedstawić ją pacjentowi. Nic tej samotności nie 
może złagodzić: poza własną wiedzą, doświadczeniem i jasnym systemem wartości. Wcale nie są rzadkie takie sytuacje, w których chirurg może uratować pacjenta tylko wówczas, gdy wybierze bardziej ryzykowną metodę. W razie niepowodzenia - straci pracę; jeśli pójdzie utartym szlakiem - pacjent zginie. Dlaczego naraża bezpieczeństwo własne i swojej rodziny? Trudno le k a r zo w i bezczynnie przyglądać się umieraniu pacjenta, jeżeli zna sposób jego uratowania. O odwadze, poczuciu zobowiązania, supererogacji piszą m.in.: Weronika Chańska ${ }^{24}$, Witold R. Jacórzyński i Marek Wichrowski ${ }^{25}$. Odwagę mają lekarze dysponujący dużą wiedzą, poświęcający setki godzin swego prywatnego czasu na prace w bibliotekach. Podobne obserwacje znajdujemy u Stefana Konstańczaka: „Przejawianie odwagi wiąże się więc z ukształtowanymi motywacjami perfekcjonistycznymi, które skłaniają do preferowania rozwiązań nadobowiązkowych kosztem własnego bezpieczeństwa"26.

Kończąc rozważania na temat decyzji operacyjnej, pragnę podzielić się spostrzeżeniami opartymi na mej własnej praktyce lekarskiej. Zdobyte własne doświadczenie ma szczególne znaczenie w medycynie, na co zwrócili już uwage Platon i Arystoteles ${ }^{27}$. Trzeba wyraźnie podkreślić konieczność omawiania zgody chorego w związku z konkretną propozycją chirurga złożoną w jasno określonych warunkach i czasie.

Decyzja o zabiegu inwazyjnym składa się z dwóch koniecznych części:

1. Decyzji chirurga, przedstawionej pacjentowi w formie propozycji.

2. Zgody lub odmowy zgody chorego.

Bez decyzji-propozycji chirurga zgoda pacjenta nie ma sensu, bez zgody pacjenta operacja zwykle się nie odbywa. Ujednolicenie formularzy zgody pacjenta nie jest dobrym rozwiązaniem.

${ }^{24}$ W. Chańska, Powiernicy? Kontrahenci? Misjonarze? Źródła i zakres obowiazków lekarzy, „Etyka” 2002, nr 35, s. 200, 202, m.in. cytuje interesujące spostrzeżenia E. Pellegrino, A. Mac Intyre'a.

${ }^{25}$ W. Jacórzyński, M. Wichrowski, Dialog pomiędzy agapista a kodeksualista, „Etyka” 26(1993), s. 83-86; W. Jacórzyński w innym artykule, idąc za J.L. Austinem, omawia wyrażenia performatywne. Stowa czy czyny, „Etyka”, 1993, nr 26, s. 233-234. Uważam, że obietnice dane pacjentowi są ważne, wiążące.

${ }^{26}$ S. Konstańczak, Blaski i cienie odwagi, „Etyka” 37(2004), s. 160.

${ }^{27}$ Arystoteles, Metafizyka, Księga A(1), tłum. K. Leśniak, Warszawa 2013, s. 23. Arystoteles cytuje tu z Platońskiego Gorgiasza Polosa, ucznia Gorgiasza, który oświadcza: „doświadczenie bowiem stworzyło wiedzę [...]”. Arystoteles tak komentuje jego wywody: „Jeżeli więc ktoś posiada teorię bez doświadczenia i wiedzę ogólną, a nie zna poszczególnych faktów objętych tą wiedzą, będzie często popełniał błędy w leczeniu; leczy się bowiem poszczególnego człowieka”. Jednocześnie krytykuje lekarzy empiryków, którzy: ,znają skutek (to oti), ale nie znają przyczyny (to dioti), a teoretycy znają i skutek, i przyczynę" - s. 23.

Zatem dzisiejszych lekarzy specjalistów Arystoteles zapewne nazwałby teoretykami. 
Małgorzata Świderska pisze: „uniformizacja mogłaby oznaczać zbyt słaba ochronę pacjenta i odhumanizowanie relacji lekarz-pacjent, która jako oparta z założenia na zaufaniu, powinna być bezpośrednia i osobowa" ${ }^{28}$. Należy przyjać trzy założenia, bez których runąć może konstrukcja wielu wspólnot:

1. Lekarz wybiera dla pacjenta rozpoznanie choroby najbardziej zbliżone do prawdy i metodę leczenia najkorzystniejszą dla pacjenta.

2. Wzajemne zaufanie pacjenta i lekarza, a szczególnie pacjenta do lekarza, jest fundamentem leczenia i nie powinno być przez nikogo niszczone.

3. Postawa życzliwości i szacunku dla osoby pacjenta umożliwia osiągnięcie porozumienia i współdziałania w leczeniu, przyczyniając się do osiągnięcia celów leczenia.

Z moich obserwacji wynika, że chirurg kierujący ostrym dyżurem nie może uniknąć samotności; musi uczyć się ją pogodnie znosić. Samotność pacjentów jest z pewnością nierzadko bardzo gorzka; może ją nieco złagodzić opiekuńcza postawa pielęgniarek i lekarzy. Są dla niektórych pacjentów jedynymi osobami, które czynami dowodzą swej życzliwości.

Bardzo niebezpiecznym zjawiskiem współczesnego świata jest upojenie różn orodności ą.

Człowiek stanowi jedność, której granice są zakreślone m.in. skórą i horyzontem intelektu.

Zabawy z awatarami i wirtualnym czasem wypychają wielu młodych z rzeczywistości, w której trzeba podejmować samodzielne decyzje o istnieniu. Analizował to zjawisko m.in. Jean Baudrillard oraz Wacław Branicki ${ }^{29}$. Czesława Piecuch, nawiązując do wypowiedzi K. Jaspersa, pisze ,[...] wolna decyzja wyraża moje «ja» i zarazem je tworzy"30.

\section{PODSUMOWANIE}

1. Konieczne jest omawianie zgody pacjenta w związku z decyzją chirurga. Dążenie do wyizolowania zagadnienia zgody pacjenta prowadzi do aporii, a w poszczególnych przypadkach do nieszczęść.

2. W czasie gdy chirurg przedstawia pacjentowi rozpoznanie i plan leczenia, pacjent nie nabywa żadnych kompetencji w dziedzinie chirurgii; jest wówczas zajęty badaniem... lekarza. Najważniejsze bowiem dla pacjenta jest to, czy może chirurgowi zaufać.

${ }^{28}$ M. Świderska, Zgoda pacjenta na zabieg medyczny, Toruń 2007, s. 353.

${ }^{29}$ W. Branicki, Tożsamość a wirtualność, Kraków 2009, szczególnie s. 22 oraz w rozdz. II Tożsamość i osoba z perspektywy tomistycznej p. 5, 6, s. 118, a w rozdz. III s. 173, 175, 176, 203.

${ }^{30}$ C. Piecuch, Otrzymać siebie $w$ darze, w: Kondycja człowieka wspótczesnego, red. C. Piecuch, Kraków 2006, s. 68. 
3. Nawet najlepiej funkcjonujące instytucje i zwyczaje wspólnoty nie mogą całkowicie usunąć samotności, szczególnie w sytuacjach graniczny ch. Nie powinny być zatem obwiniane o to, że samotność istnieje.

4. Czas jest silnym generatorem napięć związanych z samotnością. Usunięcie działań, decyzji z czasu rzeczywistego może wysuwać gracza z autentycznej egzystencji i ćwiczyć w nim bezradność w przypadku konieczności podjęcia nagłej decyzji o istnieniu.

5. Zgadzając się z N. Hartmannem, że człowiek istnieje w swych dokonaniach (im vollzuge), autor dodaje: i w decyzjach podejmowanych w samotności. Dotyczy to również twórczości.

6. Samotności w sytuacjach granicznych nie można uniknąć. Jest ceną tożsamości.

Złagodzenie samotności, w przypadku decyzji o zabiegu inwazyjnym, pacjent zawdzięcza w największym stopniu zaufaniu do lekarzy i pielęgniarek.

Poza sytuacjami granicznymi samotność nie musi być dotkliwa, o ile w ogóle jest odczuwalna. Jakże bowiem ma się pojawiać wśród przyjaciół? Czy jest możliwa na ścieżkach utorowanych przez czcigodnych naszych nauczycieli? W którąkolwiek stronę zwrócimy nasze myśli, wszędzie napotykamy ślady ich poszukiwań sprzed tysięcy lat lub nam współczesne. Jeżeli dostrzegamy to światło rzucone pod nasze stopy, z pewnością odczuwamy wdzięczność, która chroni przed samotnością.

Rozważania te pragnąłbym zakończyć cytatem z Mikołaja Bierdiajewa: „Lekarz operujący chorego mniej cierpi niż ten, kto jedynie kieruje się współczuciem, ale w niczym nie pomaga choremu"31.

\section{BIBLIOGRAFIA}

Arystoteles ze Stagiry, Metafizyka, thum. K. Leśniak, PWN, Warszawa 2013.

Bierdiajew M., Autobiografia filozoficzna, thum. H. Paprocki, Antyk, Kęty 2002.

Branicki W., Tożsamość a wirtualność, Nomos, Kraków 2009.

Cassirer E., Człowiek i kultura, w: Kierunki filozofii współczesnej, cz. II, tłum. A. Staniszewska, UMK, Torun 1995.

Chańska W., Powiernicy? Kontrahenci? Misjonarze? Źródła i zakres obowiqzków leka$r z y$, „Etyka” 35(2002), s. 191-210.

Chlewicki M., Fenomen społeczny w filozoficznym ujęciu Jose Ortegi y Gasseta, w: S. Sarnowski, M. Korzeniowska, M. Chlewicki, O metafilozofii jako filozofii filozofii, Scholar, Warszawa 2007, s. 157-170.

${ }^{31}$ M. Bierdiajew, Autobiografia filozoficzna, thum. H. Paprocki, Kęty 2002, s. 58. 
Gonet T., Problem wyboru moralnego w medycynie współczesnej, „Archiwum Historii i Filozofii Medycyny" 1988, 51, 1, s. 1-15.

Hartmann N., Myśl filozoficzna i jej historia. Systematyczna autoprezentacja, tłum. J. Garewicz, Comer, Toruń 1994.

Hobbes T., Elementy filozofii, t. 2, tłum. C. Znamierowski, PWN, Warszawa 1956.

Jacórzyński W.R., Wichrowski M., Dialog między agapista a kodeksualista, „Etyka” 1993, nr 26, s. 83-86.

Jan Paweł II, Encyklika Dives in misericordia, KAI, Warszawa 2007.

Judycki S., Intersubiektywność i czas. Przyczynek do dyskusji nad późna faza poglądów Edmunda Husserla, Tow. Nauk. KUL-u, Lublin 1990.

Kant I., Krytyka czystego rozumu, t. 1, tłum. R. Ingarden, PWN, Kraków 1957.

Konstańczak S., Blaski i cienie odwagi, „Etyka” 37(2004), s. 157-171.

Krokiewicz A., Etyka Demokryta i hedonizm Arystypa, PAX, Warszawa 1960.

Piecuch C., Otrzymać siebie w darze, w: Kondycja człowieka współczesnego, red. C. Piecuch, Wyd. Universitas, Kraków 2006.

Plessner H., Granice wspólnoty, tłum. J. Merecki, Oficyna Naukowa „N”, Warszawa 2008.

Rudziński R., Jaspers, W.P. Myśli i ludzie, Warszawa 1978.

Scheler M., Resentyment a moralność, tłum. J. Garewicz, Czytelnik, Warszawa 1997.

Storr A., Samotność - powrót do jaźni, tłum. J. Prokopiuk, P.J. Sieradzan, W.A.B., Warszawa 2010.

Szaniawski K., Teoria decyzji a etyka, „Etyka” 2(1967), s. 7-19.

Szatkowski S., Zasada nieuszkodzenia w etyce medycyny, „Etyka” 29(1996), s. 155-169.

Świderska M., Zgoda pacjenta na zabieg medyczny, Dom Organizatora, Toruń 2007.

Tyburski W., Wachowiak A., Wiśniewski R., Historia filozofii i etyki. Źródła i komentarze, TNOiK, Toruń 1997.

Tyl M., W stronę Eleusis. O ksztattowaniu się postawy religijnej Henryka Elzenberga, „Znak” 2001, nr 553, s. 95-106.

Zwoliński Z., Istota odpowiedzialności. Warunki formalne i granice, „Etyka” 26(1993), s. $13-20$.

\section{SUMMARY}

What we usually call loneliness is surely something experienced by: Palamedes and Ajax at Troy - the victims of Odysseus's envy, Antygone - after meeting her sister Ismene, Prince Hamlet - after speeking to his mother. The author added to K. Jaspers border situ ations his own loneliness research model: about invasive modality in surgery. It consists of two obligatory components parts: 1. Surgeon's decision given to the patient in the form of proposal - suggestion. 2. Patient's approval - consent. Without surgeon's proposal - patient consent is meaningless. Without the patient's approval, the operation cannot usually take place. Patient's approval, or refuse, is this part of the surgical decision, were we can distinguish: 1. Man's sovereignty in disposing of his health and life. 2. Existence of a distinct self - individuality of existence "I". The research model 
reveals, perhaps even more clearly than the another ones, the ontic dimension of loneliness. Loneliness is the price of identity - oneselfness. In conclusions the author stressed: Necessity of discussing patient's consent in conjunction with surgeon's decision. Attempts to isolate the issue of patient's approval lead to aporia, in particular cases to unhappiness. Whilst describing, by the surgeon, diagnosis and treatment plan, the patient does not gain any competence in the branch of surgery; he is preoccupied with examining the doctor. The most important thing is whether he can trust him. Even the best functioning institutions and community customs cannot remove loneliness completely, especially in border situations. Therefore they may not be blamed for the fact that the loneliness exists. Time is a strong generator of tensions connected with loneliness. Agreeing with N. Hartmann, that the man exists in his achievements, the author adds: and in decisions made in solitude. There is also creativity here.

\section{Keywords}

loneliness, solitude, community, decision in surgery, identity, patient's consent, time, invasive modality

\section{Słowa kluczowe}

samotność, wspólnota, decyzja operacyjna, tożsamość, zgoda pacjenta, czas, inwazyjny sposób leczenia 